NASA/TM-2009-215426

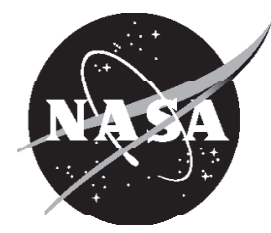

\title{
Advanced Fuel Cell System Thermal Management for NASA Exploration Missions
}

Kenneth A. Burke

Glenn Research Center, Cleveland, Ohio 


\section{NASA STI Program . . . in Profile}

Since its founding, NASA has been dedicated to the advancement of aeronautics and space science. The NASA Scientific and Technical Information (STI) program plays a key part in helping NASA maintain this important role.

The NASA STI Program operates under the auspices of the Agency Chief Information Officer. It collects, organizes, provides for archiving, and disseminates NASA's STI. The NASA STI program provides access to the NASA Aeronautics and Space Database and its public interface, the NASA Technical Reports Server, thus providing one of the largest collections of aeronautical and space science STI in the world. Results are published in both non-NASA channels and by NASA in the NASA STI Report Series, which includes the following report types:

- TECHNICAL PUBLICATION. Reports of completed research or a major significant phase of research that present the results of NASA programs and include extensive data or theoretical analysis. Includes compilations of significant scientific and technical data and information deemed to be of continuing reference value. NASA counterpart of peer-reviewed formal professional papers but has less stringent limitations on manuscript length and extent of graphic presentations.

- TECHNICAL MEMORANDUM. Scientific and technical findings that are preliminary or of specialized interest, e.g., quick release reports, working papers, and bibliographies that contain minimal annotation. Does not contain extensive analysis.

- CONTRACTOR REPORT. Scientific and technical findings by NASA-sponsored contractors and grantees.
- CONFERENCE PUBLICATION. Collected papers from scientific and technical conferences, symposia, seminars, or other meetings sponsored or cosponsored by NASA.

- SPECIAL PUBLICATION. Scientific, technical, or historical information from NASA programs, projects, and missions, often concerned with subjects having substantial public interest.

- TECHNICAL TRANSLATION. Englishlanguage translations of foreign scientific and technical material pertinent to NASA's mission.

Specialized services also include creating custom thesauri, building customized databases, organizing and publishing research results.

For more information about the NASA STI program, see the following:

- Access the NASA STI program home page at http://www.sti.nasa.gov

- E-mail your question via the Internet to help@ sti.nasa.gov

- Fax your question to the NASA STI Help Desk at 443-757-5802

- Telephone the NASA STI Help Desk at 443-757-5803

- Write to: NASA Center for AeroSpace Information (CASI) 7115 Standard Drive Hanover, MD 21076-1320 
NASA/TM-2009-215426

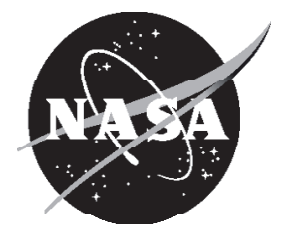

\section{Advanced Fuel Cell System Thermal Management for NASA Exploration Missions}

Kenneth A. Burke

Glenn Research Center, Cleveland, Ohio

Prepared for the

Sixth International Energy Conversion Engineering Conference and Exhibit (IECEC) sponsored by the American Institute of Aeronautics and Astronautics

Cleveland, Ohio, July 28-30, 2008

National Aeronautics and

Space Administration

Glenn Research Center

Cleveland, Ohio 44135 
Level of Review: This material has been technically reviewed by technical management.

Available from

NASA Center for Aerospace Information 7115 Standard Drive

Hanover, MD 21076-1320
National Technical Information Service 5285 Port Royal Road Springfield, VA 22161

Available electronically at http://gltrs.grc.nasa.gov 


\title{
Advanced Fuel Cell System Thermal Management for NASA Exploration Missions
}

\author{
Kenneth A. Burke \\ National Aeronautics and Space Administration \\ Glenn Research Center \\ Cleveland, Ohio 44135
}

\begin{abstract}
The NASA Glenn Research Center is developing advanced passive thermal management technology to reduce the mass and improve the reliability of space fuel cell systems for the NASA exploration program. An analysis of a state of the art fuel cell cooling systems was done to benchmark the portion of a fuel cell system's mass that is dedicated to thermal management. Additional analysis was done to determine the key performance targets of the advanced passive thermal management technology that would substantially reduce fuel cell system mass.
\end{abstract}

\section{Introduction}

The purpose of this study was to analyze a single passive cooling plate that would absorb the heat from adjacent fuel cells within a fuel cell stack system. The results of this analysis was to provide insight into the requirements of a cooling plate in terms of its thermal conductivity, thickness, and specific gravity that would result in a passive cooling system for a fuel cell stack that would provide the essential uniform thermal sink while having lower mass.

\section{Background}

The heart of a fuel cell is an electrochemical "cell" that combines a fuel and an oxidizing agent, and converts the chemical energy directly into electrical power, water and waste heat. The fuel cells used by NASA are hydrogen-oxygen fuel cells. The fuel cells likely to be used by NASA in the future are acidbased Proton Exchange Membrane (PEM) hydrogen-oxygen fuel cells. An illustration of this type of cell is shown in figure 1. A hydrogen molecule reacts at the anode to create a pair of protons and electrons. The proton ion exchange membrane conducts the protons which were generated at the anode from the anode to the cathode. The electrons which were also generated at the anode are conducted through the electrical load that is connected to the fuel cell and also reach the cathode. The hydrogen protons and the electrons are reacted at the cathode with an oxygen atom to produce a molecule of water. An illustration of a "stack" of cells connected electrically in series (shown in fig. 1) is usually employed in applications. The energy released as a result of this reaction is called the enthalpy of formation. When the product formed is liquid water (as opposed to water vapor), the enthalpy of formation is also referred to as the Higher Heating Value (HHV) of hydrogen. When the product formed is water vapor, the enthalpy of formation is referred to as the Lower Heating Value (LHV) of hydrogen. When the reaction occurs at $298 \mathrm{~K}$ the energy released is called the standard enthalpy of formation. The negative sign associated with the Gibbs free energy indicates that this reaction is spontaneous. Not all of this change in enthalpy is available for the generation of electricity. The maximum amount of energy available for the generation of 


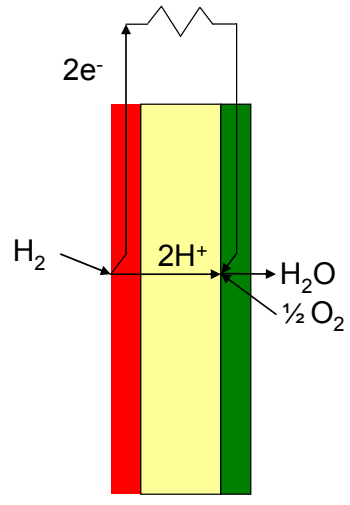

Single Cell

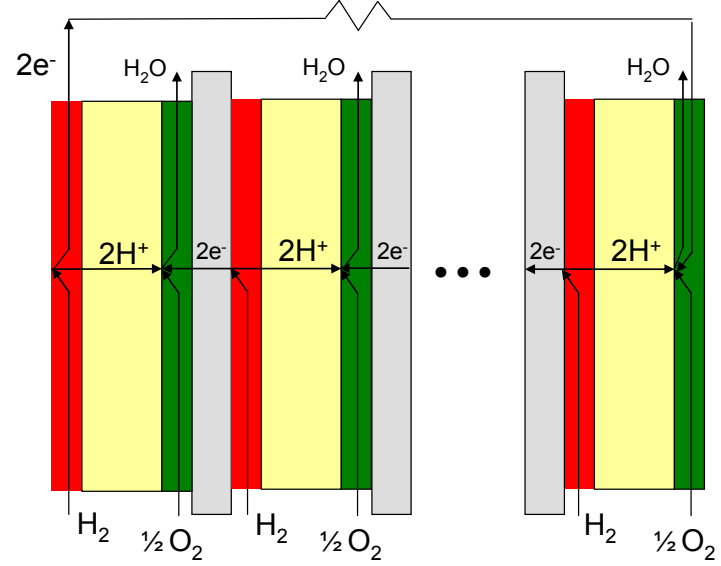

$\mathrm{n}-$ Cells in Cell Stack

$$
\begin{array}{ll}
\text { Anode Reaction } & \mathrm{H}_{2} \longrightarrow 2 \mathrm{H}^{+}+2 \mathrm{e}^{-} \\
\text {Cathode Reaction } & 1 / 2 \mathrm{O}_{2}+2 \mathrm{H}^{+}+2 \mathrm{e}^{-} \longrightarrow \mathrm{H}_{2} \mathrm{O}_{\text {liq }} \\
\hline \text { Overall Reaction } & 1 / 2 \mathrm{O}_{2}+\mathrm{H}_{2} \longrightarrow \mathrm{H}_{2} \mathrm{O}_{\text {liq }} \\
\text { Enthalpy of Formation } & \Delta_{f} H^{\circ}{ }_{298}=-285.83 \mathrm{~kJ} / \mathrm{mole} \\
\text { Gibbs Free Energy } & \Delta_{f} \mathrm{G}^{\circ}{ }_{298}=-237.14 \mathrm{~kJ} / \mathrm{mole}
\end{array}
$$

Figure 1.-Proton Exchange Membrane Fuel Cell.

electricity is the change in Gibbs free energy which is the difference between the enthalpy of formation and the energy losses associated with the change in entropy. This is described in mathematical terms as

$$
\Delta \mathrm{G}=\Delta \mathrm{H}-\mathrm{T} \Delta \mathrm{S}
$$

where

$\Delta \mathrm{G} \quad$ change in Gibbs free energy, $\mathrm{kJ} /$ mole of water formed

$\Delta \mathrm{H} \quad$ enthalpy of formation, $\mathrm{kJ} /$ mole mole of water formed

$\mathrm{T} \quad$ reaction temperature, $\mathrm{K}$

$\Delta \mathrm{S} \quad$ change in entropy, $\mathrm{kJ} / \mathrm{K} /$ mole of water formed

Table 1 shows tabulated values for the change in Gibbs free energy and the enthalpy of formation of liquid water at one atmosphere of pressure as a function of temperature.

TABLE 1.-THERMODYNAMIC PROPERTIES OF LIQUID WATER (REF. 1)

\begin{tabular}{|c|c|c|c|}
\hline $\begin{array}{c}\text { Temperature, } \\
\mathrm{K}\end{array}$ & $\begin{array}{c}\Delta \mathrm{G}, \\
\mathrm{kJ} / \mathrm{mole}\end{array}$ & $\begin{array}{c}\Delta \mathrm{H}, \\
\mathrm{kJ} / \mathrm{mole}\end{array}$ & $\begin{array}{c}\mathrm{T} \Delta \mathrm{S}, \\
\mathrm{kJ} / \mathrm{mole}\end{array}$ \\
\hline 298.15 & -237.141 & -285.830 & -48.689 \\
\hline 373.21 & -225.160 & -283.454 & -58.294 \\
\hline
\end{tabular}

It should be noted that the $\Delta \mathrm{H}$ changes very little (less than 1 percent change) from room temperature to the boiling point of water; also the $\Delta \mathrm{S}$ is negative because the entropy of the two reactant gases is greater than the product water. The reduction in entropy means there must be waste heat generated in the reaction that is released into the ambient environment (i.e. the ambient environment's entropy increases), moreover the amount of waste heat per mole increases with increasing temperature. 
The Gibbs free energy, $\Delta \mathrm{G}$ is related to the fuel cell voltage by the equation

$$
\Delta \mathrm{G}=-\mathrm{nFE}_{\mathrm{rev}}(0.001 \mathrm{~kJ} / \mathrm{W}-\mathrm{sec})
$$

where

$\mathrm{n} \quad$ number of electrons per mole of water formed (2 moles of electrons per mole of water formed)

F Faraday's constant (96,487 A-sec/mole of electrons)

$\mathrm{E}_{\text {rev }} \quad$ reversible cell voltage, Volt

Similarly, an equation can relate the enthalpy of formation, $\Delta \mathrm{H}$, to a hypothetical, thermal neutral voltage.

$$
\Delta \mathrm{H}=-\mathrm{nFE}_{\text {therm }}(0.001 \mathrm{~kJ} / \mathrm{W}-\mathrm{sec})
$$

where

$\mathrm{E}_{\text {therm }} \quad$ thermal neutral cell voltage, Volt

The calculation of the reversible cell voltage and the thermal neutral cell voltage based on the thermodynamic data contained in table 1 is shown in table 2.

TABLE 2.-REVERSIBLE CELL VOLTAGE AND

THERMAL NEUTRAL CELL VOLTAGE

\begin{tabular}{|c|c|c|c|c|}
\hline $\begin{array}{c}\text { Temperature, } \\
\mathrm{K}\end{array}$ & $\begin{array}{c}\Delta \mathrm{G}, \\
\mathrm{kJ} / \mathrm{mole}\end{array}$ & $\begin{array}{c}\Delta \mathrm{H}, \\
\mathrm{kJ} / \mathrm{mole}\end{array}$ & $\begin{array}{c}\mathrm{E}_{\text {rev }}, \\
\mathrm{V}\end{array}$ & $\begin{array}{c}\mathrm{E}_{\text {therm }}, \\
\mathrm{V}\end{array}$ \\
\hline 298.15 & -237.141 & -285.830 & 1.229 & 1.481 \\
\hline 373.21 & -225.160 & -283.454 & 1.167 & 1.469 \\
\hline
\end{tabular}

Both the reversible cell voltage and the thermal neutral cell voltage are commonly used. It is useful to compare the actual fuel cell voltage to the reversible cell voltage which represents the maximum fuel cell voltage obtainable. The thermal neutral voltage is hypothetical because as earlier stated, not all of the energy from the change in enthalpy is available to do useful work (i.e., produce a voltage). The thermal neutral voltage is useful for calculating the thermal efficiency of the fuel cell process and the waste heat generated by a fuel cell.

Several efficiencies can be calculated. A maximum theoretical energy efficiency can be calculated

$$
\eta_{\mathrm{t}}=\frac{\Delta \mathrm{G}}{\Delta \mathrm{H}}=\frac{\mathrm{E}_{\mathrm{rev}}}{\mathrm{E}_{\text {therm }}}
$$

where

$\eta_{t} \quad$ maximum theoretical energy efficiency

Using values from table 2, it can be shown that the maximum theoretical energy efficiency of a fuel cell is about 83 percent at $298 \mathrm{~K}$ and falls to about 79 percent at $373 \mathrm{~K}$. An actual energy efficiency can be calculated

$$
\eta_{\mathrm{a}}=\frac{\mathrm{W}_{\mathrm{a}}}{\Delta \mathrm{H}}=\frac{\mathrm{I}_{\mathrm{a}} \mathrm{E}_{\mathrm{a}}}{\mathrm{I}_{\mathrm{f}} \mathrm{E}_{\text {therm }}}
$$


where

$\begin{array}{ll}\eta_{\mathrm{a}} & \text { actual energy efficiency } \\ \mathrm{W}_{\mathrm{a}} & \text { actual electrical energy produced, } \mathrm{kJ} / \text { mole } \\ \mathrm{I}_{\mathrm{a}} & \text { actual fuel cell output current, Ampere } \\ \mathrm{I}_{\mathrm{f}} & \text { theoretical fuel cell output current, Ampere } \\ \mathrm{E}_{\mathrm{a}} & \text { actual fuel cell voltage, Volt }\end{array}$

It is often useful to evaluate a fuel cell's voltage performance with what is theoretically possible. A voltage efficiency can be calculated

$$
\eta_{\mathrm{v}}=\frac{\mathrm{E}_{\mathrm{a}}}{\mathrm{E}_{\mathrm{rev}}}
$$

where

$\eta_{\mathrm{v}} \quad$ voltage efficiency

Similarly, it is useful to evaluate a fuel cell's current performance with what is theoretically possible. A current efficiency can be calculated.

$$
\eta_{i}=\frac{I_{a}}{I_{f}}
$$

where

$\eta_{\mathrm{i}} \quad$ current efficiency

Equations (4), (6), and (7) can be substituted into equation (5) to yield,

$$
\eta_{\mathrm{a}}=\eta_{\mathrm{i}} \eta_{\mathrm{v}} \eta_{\mathrm{t}}
$$

To analyze the thermal management, a convenient calculation of the heat generated by a fuel cell is needed. Since all the energy that is not converted to electrical energy is dissipated as heat, the heat generated by a fuel cell can be calculated as,

$$
\mathrm{Q}=\left(\Delta \mathrm{H}-\mathrm{W}_{\mathrm{a}}\right) \dot{\mathrm{m}}_{\mathrm{H}_{2} \mathrm{O}}(1000 \mathrm{~W}-\sec / \mathrm{kJ})
$$

where

Q Waste heat generated by the fuel cell, Watt

$\dot{\mathrm{m}}_{\mathrm{H}_{2} \mathrm{O}} \quad$ fuel consumption, moles of water produced per second

Substituting equations (3) and (5) into equation (9) and simplifying,

$$
\mathrm{Q}=\left(-\mathrm{nFE}_{\text {Therm }}+\mathrm{nF}\left(\frac{\mathrm{I}_{\mathrm{a}}}{\mathrm{I}_{\mathrm{f}}}\right) \mathrm{E}_{\mathrm{a}}\right) \dot{\mathrm{m}}_{\mathrm{H}_{2} \mathrm{O}}
$$

The fuel consumption is related to the theoretical fuel cell output current as shown in equation (11). 


$$
\dot{\mathrm{m}}_{\mathrm{H}_{2} \mathrm{O}}=\frac{\mathrm{I}_{\mathrm{f}}}{\mathrm{nF}}
$$

Substituting equations (11) into equation (10) and simplifying,

$$
\mathrm{Q}=\left(-\mathrm{I}_{\mathrm{f}} \mathrm{E}_{\text {Therm }}+\mathrm{I}_{\mathrm{a}} \mathrm{E}_{\mathrm{a}}\right)
$$

Typically the actual fuel cell output current is approximately equal to the theoretical fuel cell output current. Assuming the two quantities are equal to each other, equation (12) can be further simplified to,

$$
\mathrm{Q}=\mathrm{I}_{\mathrm{f}}\left(-\mathrm{E}_{\text {Therm }}+\mathrm{E}_{\mathrm{a}}\right)
$$

Taking equation (13) and dividing by the active area of the fuel cell

$$
\frac{\mathrm{Q}}{\mathrm{A}}=\frac{\mathrm{I}_{\mathrm{f}}}{\mathrm{A}}\left(-\mathrm{E}_{\text {Therm }}+\mathrm{E}_{\mathrm{a}}\right)=\mathrm{q}=\mathrm{i}_{\mathrm{f}}\left(-\mathrm{E}_{\text {Therm }}+\mathrm{E}_{\mathrm{a}}\right)
$$

where

q fuel cell waste heat density, W/ $/ \mathrm{cm}^{2}$

$i_{f} \quad$ theoretical fuel cell output current density, $\mathrm{mA} / \mathrm{cm}^{2}$

A Total active area of the fuel cell stack, $\mathrm{m}^{2}$

$\mathrm{A}_{\text {cell }} \quad$ Active area of a single cell in the fuel cell stack, $\mathrm{m}^{2}$

Figure 2 plots the fuel cell heat generation density (the heat generated per unit of cell area) versus the fuel cell output current density (ref. 2). NASA's fuel cell applications typically optimize in the lower current density range $\left(\leq 400 \mathrm{~mA} / \mathrm{cm}^{2}\right)$, so the heat generation expected from NASA's fuel cells is generally $\leq 0.3 \mathrm{~W} / \mathrm{cm}^{2}$.

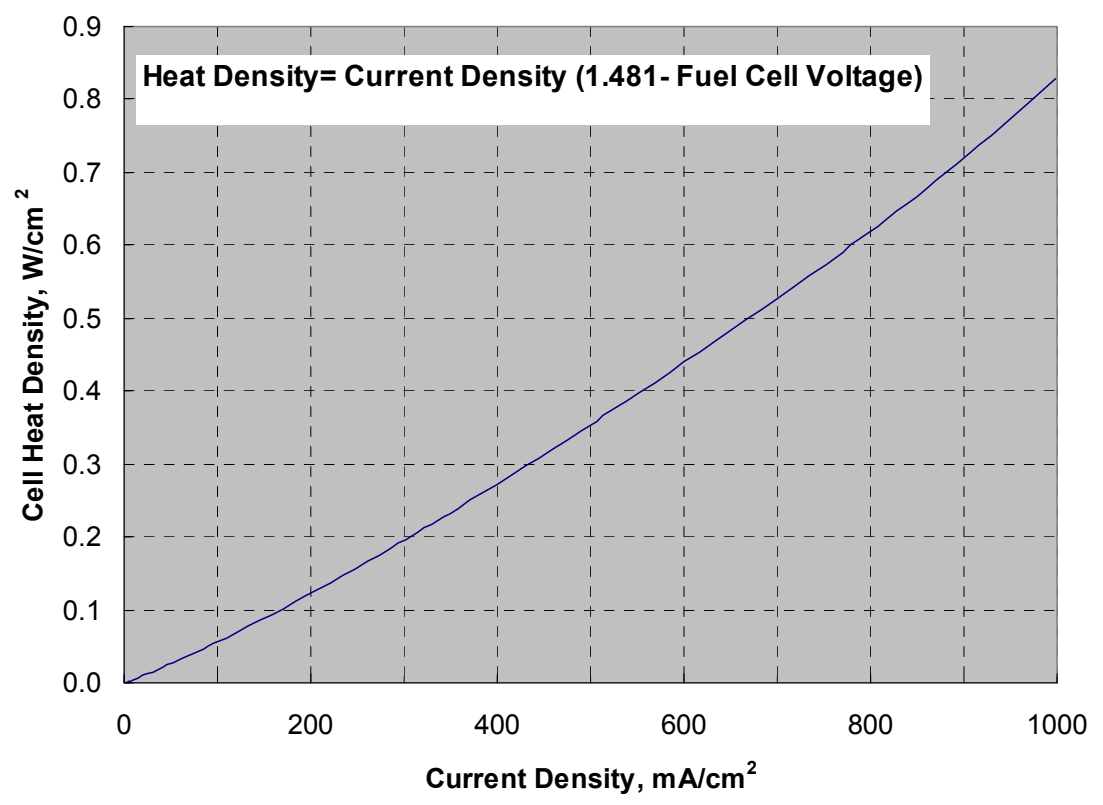

Figure 2.-Fuel cell heat generation, $\mathrm{A} / \mathrm{cm}^{2}$. 


\section{Fuel Cell Active Area Cooling Analysis}

An analytical model of a typical fuel cell cooling plate is shown in figure 3 . Heat is absorbed from the fuel cells on either side of the cooling plate. Typically a liquid coolant is circulated within the plate and heat is removed convectively as the coolant passes through plate and out of the fuel cell stack. A passive cooling plate must conduct the heat within the plane of the plate out to one or more of the edges of the plate so that the heat can be transferred to a heat sink external to the fuel cell stack. Figure 4 shows the difference between a conventional fuel cell thermal management system and a passive fuel cell thermal management system. The benefits of the passive approach are reductions in mass, system complexity, and parasitic power as well as improvements in system reliability.

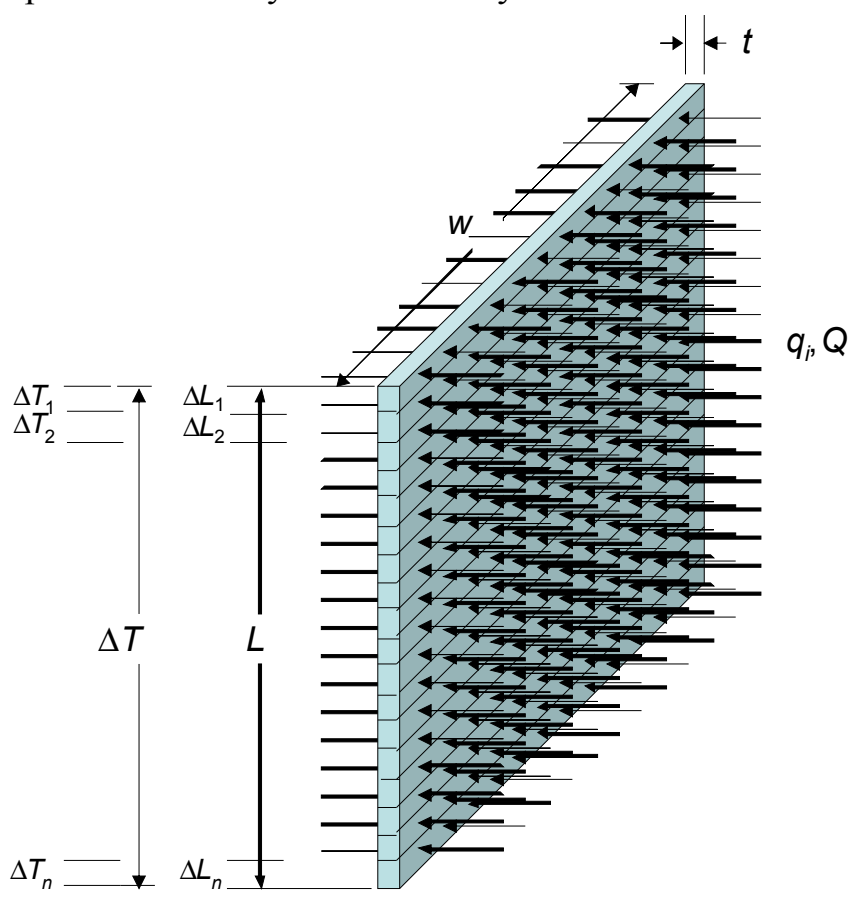

Figure 3.-Fuel cell cooling plate model.
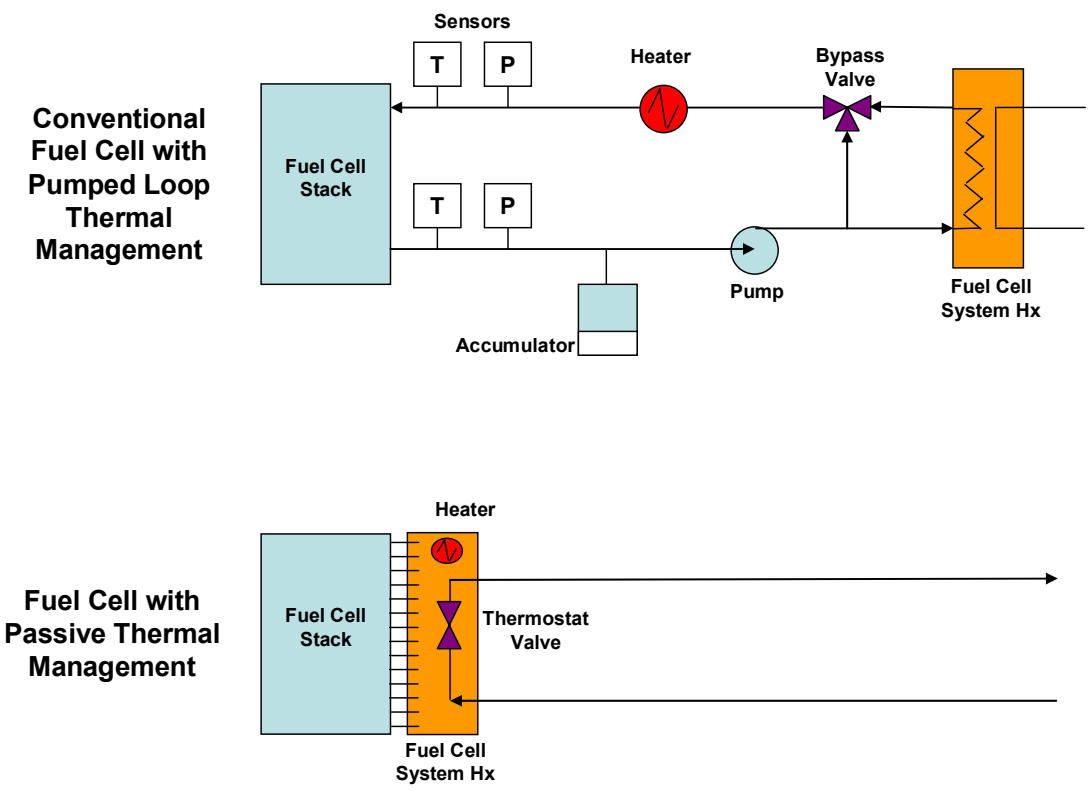

Figure 4.-Fuel Cell Thermal Management Systems. 
The key to making the passive approach workable is making the cooling plates light enough yet highly thermally conductive so that the heat can be effectively removed and also provide each cell in the fuel cell stack a thermally uniform heat sink. Analytical expressions are needed to relate the thermal performance of a passive cooling plate to its physical characteristics. In this analysis the cooling plate is modeled as a series of small planar elements stacked edge to edge. The total amount of heat entering the first, top-most plate (from both sides) is

$$
\Delta \mathrm{Q}_{1}=\mathrm{q}_{1} \Delta \mathrm{A}_{1}
$$

where

$\Delta \mathrm{Q}_{1} \quad$ heat transferred through the $1^{\text {st }}$ planar element, Watt

$\mathrm{q}_{1} \quad$ heat density absorbed by the $1^{\text {st }}$ planar element, $\mathrm{W} / \mathrm{cm}^{2}$

$\Delta \mathrm{A}_{1} \quad$ surface area of the $1^{\text {st }}$ planar element, $\mathrm{cm}^{2}$

The heat absorbed by the first planar element must be conducted to the next lower plate. This heat can be approximated as

$$
\Delta \mathrm{Q}_{1}=\frac{\left(\mathrm{ktw} \Delta \mathrm{T}_{1}\right)}{\Delta \mathrm{L}_{1}}
$$

where

$\mathrm{k}$ thermal Conductivity of the planar material, $\mathrm{W} / \mathrm{m} / \mathrm{K}$

$\mathrm{t}$ thickness of the planar material, $\mathrm{cm}$

w width of the planar elements, $\mathrm{cm}$

$\Delta \mathrm{T}_{1} \quad$ in-plane temperature differential of the $1^{\text {st }}$ planar element, $\mathrm{K}$

$\Delta \mathrm{L}_{1} \quad$ length of the $1^{\text {st }}$ planar element, $\mathrm{cm}$

Equating $\Delta \mathrm{Q}_{1}$ from equation (15) with $\Delta \mathrm{Q}_{1}$ from equation (16) yields,

$$
\frac{\left(\mathrm{ktw} \Delta \mathrm{T}_{1}\right)}{\Delta \mathrm{L}_{1}}=\mathrm{q}_{1} \Delta \mathrm{A}_{1}
$$

Solving for $\Delta \mathrm{T}_{1}$

$$
\Delta \mathrm{T}_{1}=\frac{\left(\mathrm{q}_{1} \Delta \mathrm{A}_{1}\right) \Delta \mathrm{L}_{1}}{\mathrm{ktw}}
$$

A similar expression can be written for $\Delta \mathrm{T}_{2}, \Delta \mathrm{T}_{3}$, and $\Delta \mathrm{T}_{\mathrm{N}}$. Assuming $\Delta \mathrm{L}_{1}=\Delta \mathrm{L}_{2}=\Delta \mathrm{L}_{3}=\Delta \mathrm{L}_{\mathrm{N}}=\Delta \mathrm{L}$, and $\Delta \mathrm{A}_{1}=\Delta \mathrm{A}_{2}=\Delta \mathrm{A}_{3}=\Delta \mathrm{A}_{\mathrm{N}}=\Delta \mathrm{A}$

$$
\begin{gathered}
\Delta \mathrm{T}_{2}=\frac{\left(\mathrm{q}_{1} \Delta \mathrm{A}+\mathrm{q}_{2} \Delta \mathrm{A}\right) \Delta \mathrm{L}}{\mathrm{ktw}} \\
\Delta \mathrm{T}_{3}=\frac{\left(\mathrm{q}_{1} \Delta \mathrm{A}+\mathrm{q}_{2} \Delta \mathrm{A}+\mathrm{q}_{3} \Delta \mathrm{A}\right) \Delta \mathrm{L}}{\mathrm{ktw}} \\
\Delta \mathrm{T}_{\mathrm{N}}=\frac{\left(\mathrm{q}_{1} \Delta \mathrm{A}+\mathrm{q}_{2} \Delta \mathrm{A}+\mathrm{q}_{3} \Delta \mathrm{A}+\cdots+\mathrm{q}_{\mathrm{N}} \Delta \mathrm{A}\right) \Delta \mathrm{L}}{\mathrm{ktw}}
\end{gathered}
$$


where

$\Delta \mathrm{T}_{2} \quad$ in-plane temperature differential of the $2^{\text {nd }}$ planar element, $\mathrm{K}$

$\Delta \mathrm{T}_{3} \quad$ in-plane temperature differential of the $3^{\text {rd }}$ planar element, $\mathrm{K}$

$\Delta \mathrm{T}_{\mathrm{N}} \quad$ in-plane temperature differential of the $\mathrm{N}^{\text {th }}$ planar element, $\mathrm{K}$

$\mathrm{q}_{2} \quad$ heat density absorbed by the $2^{\text {nd }}$ planar element, $\mathrm{W} / \mathrm{cm}^{2}$

$\mathrm{q}_{3} \quad$ heat density absorbed by the $3^{\text {rd }}$ planar element, $\mathrm{W} / \mathrm{cm}^{2}$

$\mathrm{q}_{\mathrm{N}} \quad$ heat density absorbed by the $\mathrm{N}^{\text {th }}$ planar element, $\mathrm{W} / \mathrm{cm}^{2}$

Assuming that the heat density absorbed by all the planar elements is uniform,

$$
\mathrm{q}_{1}=\mathrm{q}_{2}=\mathrm{q}_{3}=\cdots=\mathrm{q}_{\mathrm{N}}=\mathrm{q}
$$

If equations (19), (20), (21) and all such similar expressions for the temperature differentials of all the individual planar elements $\Delta \mathrm{T}_{1}$ through $\Delta \mathrm{T}_{\mathrm{N}}$ are added together and factoring out the common factors of $\mathrm{q}, \Delta \mathrm{A}$, and $\Delta \mathrm{L}$

$$
\sum_{1}^{\mathrm{N}} \Delta \mathrm{T}_{\mathrm{i}}=\frac{(\mathrm{N}+(\mathrm{N}-1)+(\mathrm{N}-2)+\cdots+1) \mathrm{q} \Delta \mathrm{A} \Delta \mathrm{L}}{\mathrm{ktw}}
$$

It can be recognized that

$$
\begin{gathered}
\sum_{1}^{\mathrm{N}} \Delta \mathrm{T}_{\mathrm{i}}=\Delta \mathrm{T} \\
\Delta \mathrm{A}=\Delta \mathrm{LW} \\
\Delta \mathrm{L}=\frac{\mathrm{L}}{\mathrm{N}}
\end{gathered}
$$

where

$\Delta \mathrm{T} \quad$ total in-plane temperature differential across the cooling plate, $\mathrm{K}$

$\mathrm{L} \quad$ total length of the cooling plate, $\mathrm{cm}$

$\mathrm{N}$ total number of planar elements

Substituting equations (24), (25), and (26) into equation (23)

$$
\Delta \mathrm{T}=\frac{(\mathrm{N}+(\mathrm{N}-1)+(\mathrm{N}-2)+\cdots+1) \mathrm{qL}^{2}}{\mathrm{~N}^{2} \mathrm{kt}}
$$

Lastly, the infinite series shown in equation (26) can be rewritten as

$$
\mathrm{N}+(\mathrm{N}-1)+(\mathrm{N}-2)+\cdots+1=\frac{\mathrm{N}(\mathrm{N}-1)}{2}
$$

Substituting equation (28) into equation (27) yields 


$$
\Delta \mathrm{T}=\frac{(\mathrm{N}(\mathrm{N}-1)) \mathrm{qL}^{2}}{2 \mathrm{~N}^{2} \mathrm{kt}}
$$

As $\mathrm{N} \rightarrow \infty$, equation (29) can be rewritten as

$$
\Delta \mathrm{T}=\frac{\mathrm{qL}^{2}}{2 \mathrm{kt}}
$$

For fuel cell applications it is ideal to have $\Delta \mathrm{T}=0$, but practically speaking, a $\Delta \mathrm{T} \leq 3{ }^{\circ} \mathrm{C}$ is acceptable. The reasons are two-fold, first, the fuel cell chemical process kinetics are temperature sensitive. Nonuniformity in the temperature of the fuel cell electrodes means some areas of the electrodes are going to be more active than other areas on the fuel cell electrodes. The second reason is that the water movement within the fuel cell is affected by local variations in the water vapor pressure (which is a function of the water temperature).

The fuel cell heat loads expected from NASA applications is $\leq 0.3 \mathrm{~W} / \mathrm{cm}^{2}$. The heat loads of fuel cells vary depending on their operating current density, but generally speaking these heat loads are small when compared with microelectronics heat loads which can exceed $100 \mathrm{~W} / \mathrm{cm}^{2}$. NASA's fuel cell applications generally optimize at low current densities because the high voltage efficiency that results from operating at low current densities minimizes fuel consumption and overall spacecraft mass. Using the constraints on $\Delta \mathrm{T}$ and $\mathrm{q}$, a relationship between $\mathrm{L}, \mathrm{k}$ and $\mathrm{t}$ is plotted in figure 5 .

Figure 5 shows that for even small fuel cells, where the heat transmission distance is $5 \mathrm{~cm}$ or less the conductivity requirements are high. While the thermal conductivity requirements are reduced for thicker plates, thicker plates rapidly increase the mass of the fuel cell stack. The values of the cooling plate thicknesses that are plotted are representative of the cooling compartments currently in fuel cell stacks. Figure 5 shows that copper which has a thermal conductivity of $400 \mathrm{~W} / \mathrm{m} / \mathrm{K}$ would be adequate only for heat transmission distances of $4 \mathrm{~cm}$ or less unless cooling plates $\geq 2 \mathrm{~mm}$ were used. Diamond, which has a thermal conductivity of $2300 \mathrm{~W} / \mathrm{m} / \mathrm{K}$, is the most thermally conductive material known, and it would be adequate for heat transmission distances up to about $8 \mathrm{~cm}$. Considering these material constraints, it is understandable why passive thermal systems for fuel cells have not been developed.

Aside from providing a uniform thermal environment for the fuel cell, it is also important that the mass of the cooling system be minimized. A metric used to evaluate the mass properties of a fuel cell system's cooling subsystem is to calculate the ratio of the waste heat handled by the cooling system to the mass of the cooling system components. For a typical liquid-cooled fuel cell system, the mass includes

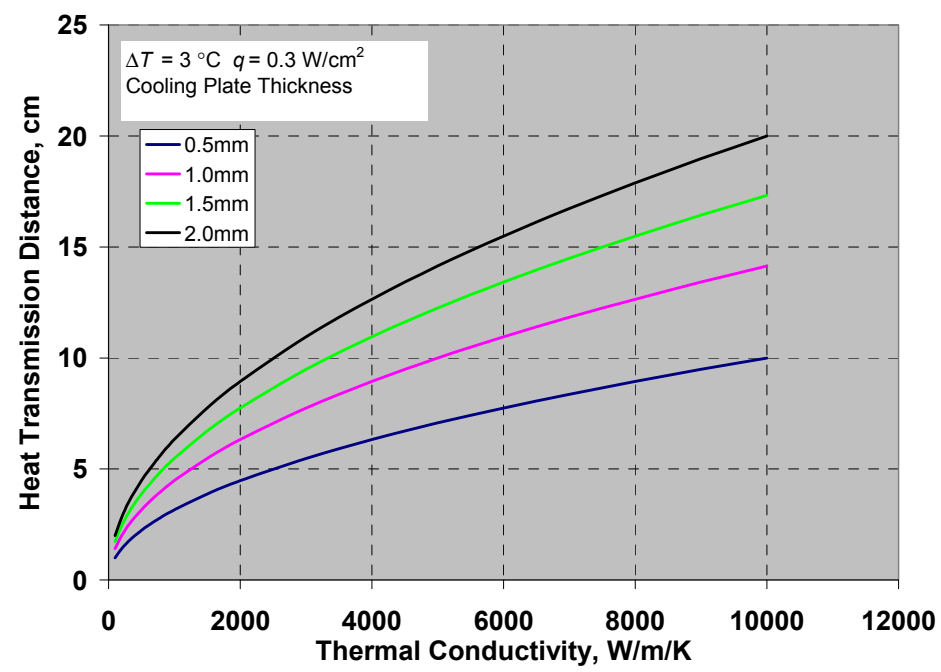

Figure 5.-Cooling plate heat transmission distance, thermal conductivity, and thickness. 
the cooling cells within the cell stack as well as the cooling system components outside the cell stack (e.g., tubing, fittings, coolant, sensors, accumulator, etc.). This ratio should be calculated at the maximum heat dissipation since it is the maximum heat dissipation which sizes the cooling system. A cooling system mass metric of $556 \mathrm{~W} / \mathrm{kg}$ was calculated for a fuel cell system tested at the NASA Glenn Research Center. As a goal for an advanced passive thermal management system a cooling system mass metric of $1000 \mathrm{~W} / \mathrm{kg}$ was selected. This metric can be incorporated into equation (30) in the following manner.

The fuel cell waste heat density, q can be thought of as the fuel cell waste heat per cell applied to the cooling plate divided by the planar area of the cooling plate. Using the active area of a single cell in the fuel cell stack as the planar area of the cooling plate,

$$
\mathrm{q}=\frac{\mathrm{Q}_{\text {plate }}}{\mathrm{A}_{\text {cell }}}
$$

where

$\mathrm{Q}_{\text {plate }} \quad$ Fuel cell waste heat per cell absorbed by a single cooling plate, watt

$\mathrm{A}_{\text {cell }} \quad$ Active area of a single cell in the fuel cell stack, $\mathrm{m}^{2}$

Substituting equation (31) into equation (30) results in

$$
\Delta \mathrm{T}=\frac{\mathrm{Q}_{\text {plate }} \mathrm{L}^{2}}{2 \mathrm{kA}_{\text {cell }}}
$$

Recognizing that the area times the thickness of the plate is the plate volume, equation (32) can be rewritten as

$$
\Delta \mathrm{T}=\frac{\mathrm{Q}_{\text {plate }} \mathrm{L}^{2}}{2 \mathrm{kV}}
$$

where

$\mathrm{V}$ total volume of the cooling plate, $\mathrm{cm}^{3}$

The mass of the cooling plate is related to the volume of the cooling plate if an assumption of uniform mass density is made.

$$
\rho=\frac{M}{V}
$$

Solving equation (34) for plate volume and substituting this into equation (33) results in

$$
\Delta \mathrm{T}=\frac{\mathrm{QL}^{2} \rho}{2 \mathrm{kM}}
$$

Recognizing the ratio of $\mathrm{Q} / \mathrm{M}$ as the cooling system mass metric

$$
\Delta \mathrm{T}=\left(\frac{\mathrm{Q}}{\mathrm{M}}\right) \frac{\mathrm{L}^{2} \rho}{2 \mathrm{k}}
$$




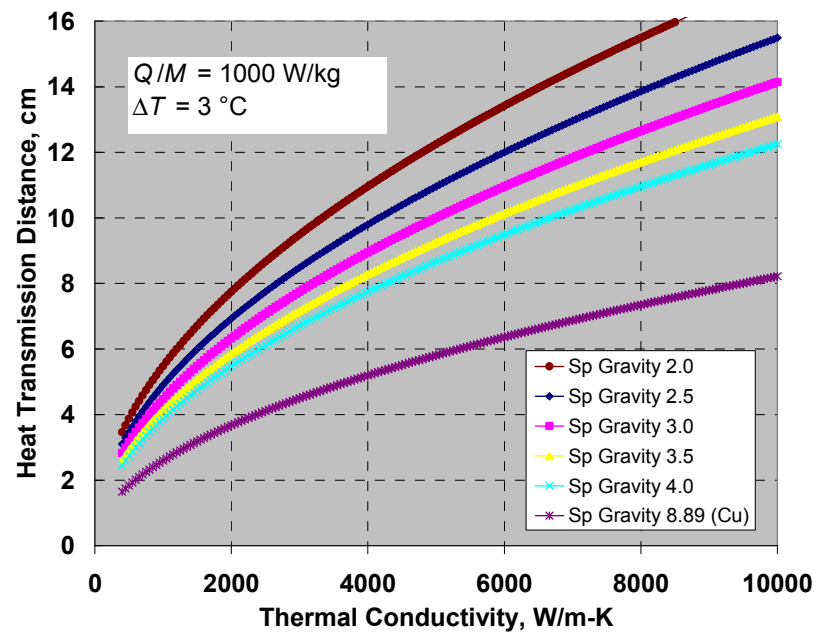

Figure 6.-Cooling plate heat transmission distance, thermal conductivity, and plate specific gravity.

Using the $1000 \mathrm{~W} / \mathrm{kg}$ as the value of the metric, and $3{ }^{\circ} \mathrm{C}$ as the $\Delta \mathrm{T}$, a relationship between $\mathrm{L}, \rho$, and the average density of the cooling plate is plotted in figure 6.

Figure 6 shows that metals such as copper (specific gravity of 8.89 and thermal conductivity of $400 \mathrm{~W} / \mathrm{m} / \mathrm{K}$ ) and aluminum (specific gravity of 2.7 and thermal conductivity of $180 \mathrm{~W} / \mathrm{m} / \mathrm{K}$ ) which are used in cooling applications in general, are clearly unsuitable for fuel cell cooling except for very small fuel cells. Table 4 lists alternative high thermally conductive materials (ref. 3). These alternative materials are all carbon based: diamond, diamond composites, pyrolytic graphite, and graphite composites. Highly Oriented Pyrolytic Graphite (HOPG) has the best combination of high thermal conductivity and low specific gravity. HOPG appears to meet the criteria if the heat transmission distance is less than 7 centimeters.

TABLE 4.-ALTERNATE PASSIVE COOLING PLATE MATERIALS (REF. 3)

\begin{tabular}{|l|c|c|}
\hline \multicolumn{1}{|c|}{ Material } & $\begin{array}{c}\text { Thermal conductivity, } \\
\mathrm{W} / \mathrm{m}-\mathrm{K}\end{array}$ & $\begin{array}{c}\text { Specific gravity, } \\
\mathrm{g} / \mathrm{cm}^{3}\end{array}$ \\
\hline CVD diamond & $1100-1800$ & 3.5 \\
\hline HOPG* & $1500-1700$ & 2.3 \\
\hline Natural graphite & 500 & ------ \\
\hline Cont. $\mathrm{CF} / \mathrm{Cu}^{*}$ & $400-420$ & $5.3-8.2$ \\
\hline Carbon/carbon* & $400(690)$ & 1.9 \\
\hline Gr flake/Al* & $400-600$ & 2.3 \\
\hline Diamond/Cu & $600-1200$ & 5.9 \\
\hline Diamond/Al & $550-600$ & 3.1 \\
\hline
\end{tabular}

In addition to these materials, heat pipes, which use phase changes to absorb and reject heat are capable of extremely high effective thermal conductivities, and also are candidates for passive cooling plates. Heat pipes are probably the only candidate capable of passively moving the heat for large fuel cells (transmission distances of $\geq 10 \mathrm{~cm}$ ). 


\section{Conclusions}

This analysis of a passive approach to fuel cell thermal management leads to the following conclusions:

1. Passive cooling can be done, but in general, it requires either low heat transmission distances $(\leq 10 \mathrm{~cm})$, very high thermal conductivity $(\geq 1000 \mathrm{~W}$-m/K), or very thick cooling plates. Making thick cooling plates is counter to NASA's goal of reducing the fuel cell stack mass.

2. There are alternative materials whose thermal conductivity is high enough to move the heat $\leq 10 \mathrm{~cm}$. These materials are diamond, diamond composites or HOPG. Heat pipes are also a potential alternative, and probably the only viable approach for passive heat removal in large fuel cells.

3. The mass of a passive fuel cell thermal management system is potentially about half of that of a conventional fuel cell cooling system.

\section{References}

1. CRC Handbook of Thermophysical and Thermochemical Data, David R. Lide, Henry V. Kehiaian, CRC Press, 1994.

2. Calculated from data taken from Kenneth A. Burke, "Small portable PEM Fuel Cell Systems for NASA Exploration Missions", NASA/TM-2005-213994, AIAA-2005-5680 December 2005.

3. Zweben, Carl "New, Ultrahigh-Thermal-Conductivity Packaging Materials," IEEE Components, Packaging \& Manufacturing Technology Society-Santa Clara Valley Chapter, Sunnyvale, CA, March 16, 2005. 


\section{Appendix-Symbols}

A total active area of the cooling plate, $\mathrm{cm}^{2}$

$\mathrm{A}_{\text {cell }} \quad$ active area of a single cell in the fuel cell stack, $\mathrm{m}^{2}$

$\mathrm{E}_{\mathrm{a}} \quad$ actual fuel cell voltage, Volt

$\mathrm{E}_{\mathrm{rev}} \quad$ reversible cell voltage, Volt

$\mathrm{E}_{\text {therm }} \quad$ thermal neutral cell voltage, Volt

F Faraday's constant (96,487 A-sec/mole of electrons)

$\mathrm{I}_{\mathrm{a}} \quad$ actual fuel cell output current, Ampere

$\mathrm{I}_{\mathrm{f}} \quad$ theoretical fuel cell output current, Ampere

$\mathrm{L}$ total length of the cooling plate, $\mathrm{cm}$

$\mathrm{N} \quad$ total number of planar elements

Q Waste heat generated by the fuel cell, Watts

$Q_{\text {plate }} \quad$ Fuel cell waste heat per cell absorbed by a single cooling plate, Watts

$\Delta$ Q1 Heat transferred through the 1st planar element, Watts

$\mathrm{T}$ reaction temperature, $\mathrm{K}$

$\mathrm{V}$ total volume of the cooling plate, $\mathrm{cm}^{3}$

$\mathrm{W}_{\mathrm{a}} \quad$ actual electrical energy produced, $\mathrm{kJ} / \mathrm{mole}$

$i_{\mathrm{f}} \quad$ theoretical fuel cell output current density, $\mathrm{mA} / \mathrm{cm}^{2}$

$\mathrm{k}$ thermal Conductivity of the planar material, $\mathrm{W} / \mathrm{m} / \mathrm{K}$

$\dot{\mathrm{m}}_{\mathrm{H}_{2} \mathrm{O}}$ fuel consumption, moles of water produced per second

$\mathrm{n} \quad$ number of electrons per mole of water formed (2 moles of electrons per mole of water formed)

q fuel cell waste heat density, $\mathrm{W} / \mathrm{cm}^{2}$

$\mathrm{q}_{1} \quad$ heat density absorbed by the $1^{\text {st }}$ planar element, $\mathrm{W} / \mathrm{cm}^{2}$

$\mathrm{q}_{2} \quad$ heat density absorbed by the $2^{\text {nd }}$ planar element, $\mathrm{W} / \mathrm{cm}^{2}$

$\mathrm{q}_{3} \quad$ heat density absorbed by the $3^{\text {rd }}$ planar element, $\mathrm{W} / \mathrm{cm}^{2}$

$\mathrm{q}_{\mathrm{n}} \quad$ heat density absorbed by the $\mathrm{n}^{\text {th }}$ planar element, $\mathrm{W} / \mathrm{cm}^{2}$

$\mathrm{t} \quad$ thickness of the planar material, $\mathrm{cm}$

W width of the planar elements, $\mathrm{cm}$

$\Delta \mathrm{A}_{1} \quad$ surface area of the $1^{\text {st }}$ planar element, $\mathrm{cm}^{2}$

$\Delta \mathrm{A}_{2} \quad$ surface area of the $2^{\text {nd }}$ planar element, $\mathrm{cm}^{2}$

$\Delta \mathrm{A}_{3} \quad$ surface area of the $3^{\text {rd }}$ planar element, $\mathrm{cm}^{2}$

$\Delta \mathrm{A}_{\mathrm{n}} \quad$ surface area of the $\mathrm{n}^{\text {th }}$ planar element, $\mathrm{cm}^{2}$

$\Delta \mathrm{A} \quad$ surface area of the each planar element, $\mathrm{cm}^{2}$

$\Delta \mathrm{G} \quad$ change in Gibbs free energy, $\mathrm{kJ} /$ mole of water formed

$\Delta \mathrm{H} \quad$ enthalpy of formation, $\mathrm{kJ} / \mathrm{mole}$ mole of water formed

$\Delta \mathrm{L}_{1} \quad$ length of the $1^{\text {st }}$ planar element, $\mathrm{cm}$

$\Delta \mathrm{L}_{2} \quad$ length of the $2^{\text {nd }}$ planar element, $\mathrm{cm}$

$\Delta \mathrm{L}_{3} \quad$ length of the $3^{\text {rd }}$ planar element, $\mathrm{cm}$ 


$\begin{array}{ll}\Delta \mathrm{L}_{\mathrm{n}} & \text { length of the } \mathrm{n}^{\text {th }} \text { planar element, } \mathrm{cm} \\ \Delta \mathrm{L} & \text { length of the each planar element, } \mathrm{cm} \\ \Delta \mathrm{Q}_{1} & \text { heat transferred through the } 1^{\text {st }} \text { planar element, Watts } \\ \Delta \mathrm{S} & \text { change in entropy, } \mathrm{kJ} / \mathrm{K} / \text { mole of water formed } \\ \Delta \mathrm{T} & \text { total in-plane temperature differential across the cooling plate, } \mathrm{K} \\ \Delta \mathrm{T}_{1} & \text { in-plane temperature differential of the } 1^{\text {st }} \text { planar element, } \mathrm{K} \\ \Delta \mathrm{T}_{2} & \text { in-plane temperature differential of the } 2^{\text {nd }} \text { planar element, } \mathrm{K} \\ \Delta \mathrm{T}_{3} & \text { in-plane temperature differential of the } 3^{\text {rd }} \text { planar element, } \mathrm{K} \\ \Delta \mathrm{T}_{\mathrm{n}} & \text { in-plane temperature differential of the } \mathrm{n}^{\text {th }} \text { planar element, } \mathrm{K} \\ \eta_{\mathrm{a}} & \text { actual energy efficiency } \\ \eta_{\mathrm{i}} & \text { current efficiency } \\ \eta_{\mathrm{t}} & \text { maximum theoretical energy efficiency } \\ \eta_{\mathrm{v}} & \text { voltage efficiency }\end{array}$




\begin{tabular}{|c|c|c|c|c|c|}
\hline \multicolumn{5}{|c|}{ REPORT DOCUMENTATION PAGE } & $\begin{array}{l}\text { Form Approved } \\
\text { OMB No. 0704-0188 }\end{array}$ \\
\hline \multicolumn{6}{|c|}{$\begin{array}{l}\text { The public reporting burden for this collection of information is estimated to average } 1 \text { hour per response, including the time for reviewing instructions, searching existing data sources, gathering and maintaining the } \\
\text { data needed, and completing and reviewing the collection of information. Send comments regarding this burden estimate or any other aspect of this collection of information, including suggestions for reducing this } \\
\text { burden, to Department of Defense, Washington Headquarters Services, Directorate for Information Operations and Reports ( } 0704-0188 \text {, } 1215 \text { Jefferson Davis Highway, Suite } 1204 \text {, Arlington, VA } 22202-4302 \text {. } \\
\text { Respondents should be aware that notwithstanding any other provision of law, no person shall be subject to any penalty for failing to comply with a collection of information if it does not display a currently valid OMB } \\
\text { control number. } \\
\text { PLEASE DO NOT RETURN YOUR FORM TO THE ABOVE ADDRESS. }\end{array}$} \\
\hline \multicolumn{2}{|c|}{$\begin{array}{l}\text { 1. REPORT DATE (DD-MM-YYYY) } \\
01-06-2009\end{array}$} & \multicolumn{3}{|c|}{$\begin{array}{l}\text { 2. REPORT TYPE } \\
\text { Technical Memorandum }\end{array}$} & 3. DATES COVERED (From - To) \\
\hline \multirow{3}{*}{\multicolumn{5}{|c|}{$\begin{array}{l}\text { 4. TITLE AND SUBTITLE } \\
\text { Advanced Fuel Cell System Thermal Management for NASA Exploration Missions }\end{array}$}} & 5a. CONTRACT NUMBER \\
\hline & & & & & 5b. GRANT NUMBER \\
\hline & & & & & 5c. PROGRAM ELEMENT NUMBER \\
\hline \multirow{3}{*}{\multicolumn{5}{|c|}{$\begin{array}{l}\text { 6. AUTHOR(S) } \\
\text { Burke, Kenneth, A. }\end{array}$}} & 5d. PROJECT NUMBER \\
\hline & & & & & 5e. TASK NUMBER \\
\hline & & & & & $\begin{array}{l}\text { 5f. WORK UNIT NUMBER } \\
\text { WBS 038957.04.06.01 }\end{array}$ \\
\hline \multicolumn{5}{|c|}{$\begin{array}{l}\text { 7. PERFORMING ORGANIZATION NAME(S) AND ADDRESS(ES) } \\
\text { National Aeronautics and Space Administration } \\
\text { John H. Glenn Research Center at Lewis Field } \\
\text { Cleveland, Ohio 44135-3191 }\end{array}$} & $\begin{array}{l}\text { 8. PERFORMING ORGANIZATION } \\
\text { REPORT NUMBER } \\
\text { E-16595 }\end{array}$ \\
\hline \multirow{2}{*}{\multicolumn{5}{|c|}{$\begin{array}{l}\text { 9. SPONSORING/MONITORING AGENCY NAME(S) AND ADDRESS(ES) } \\
\text { National Aeronautics and Space Administration } \\
\text { Washington, DC 20546-0001 }\end{array}$}} & $\begin{array}{l}\text { 10. SPONSORING/MONITOR'S } \\
\text { ACRONYM(S) } \\
\text { NASA }\end{array}$ \\
\hline & & & & & $\begin{array}{l}\text { 11. SPONSORING/MONITORING } \\
\text { REPORT NUMBER } \\
\text { NASA/TM-2009-215426 }\end{array}$ \\
\hline \multicolumn{6}{|c|}{$\begin{array}{l}\text { 12. DISTRIBUTION/AVAILABILITY STATEMENT } \\
\text { Unclassified-Unlimited } \\
\text { Subject Categories: } 20 \text { and } 44 \\
\text { Available electronically at http://gltrs.grc.nasa.gov } \\
\text { This publication is available from the NASA Center for AeroSpace Information, 301-621-0390 }\end{array}$} \\
\hline \multicolumn{6}{|c|}{ 13. SUPPLEMENTARY NOTES } \\
\hline \multicolumn{6}{|c|}{$\begin{array}{l}\text { 14. ABSTRACT } \\
\text { The NASA Glenn Research Center is developing advanced passive thermal management technology to reduce the mass and improve the } \\
\text { reliability of space fuel cell systems for the NASA exploration program. An analysis of a state-of-the-art fuel cell cooling systems was done } \\
\text { to benchmark the portion of a fuel cell system's mass that is dedicated to thermal management. Additional analysis was done to determine } \\
\text { the key performance targets of the advanced passive thermal management technology that would substantially reduce fuel cell system mass. }\end{array}$} \\
\hline \multicolumn{6}{|c|}{$\begin{array}{l}\text { 15. SUBJECT TERMS } \\
\text { Fuel cell power plants; Electric power supplies; Energy sources; Spacecraft power supplies; Electric power; Energy storage; Fuel cells }\end{array}$} \\
\hline \multicolumn{3}{|c|}{ 16. SECURITY CLASSIFICATION OF: } & $\begin{array}{l}\text { 17. LIMITATION OF } \\
\text { ABSTRACT }\end{array}$ & $\begin{array}{l}\text { 18. NUMBER } \\
\text { OF }\end{array}$ & $\begin{array}{l}\text { 19a. NAME OF RESPONSIBLE PERSON } \\
\text { STI Help Desk (email:help } @ \text { sti.nasa.gov) }\end{array}$ \\
\hline $\begin{array}{l}\text { a. REPORT } \\
\text { U }\end{array}$ & $\begin{array}{l}\text { b. ABSTRACT } \\
\text { U }\end{array}$ & $\begin{array}{l}\text { c. THIS } \\
\text { PAGE } \\
\text { U }\end{array}$ & $\mathrm{UU}$ & $\begin{array}{c}\text { PAGES } \\
20\end{array}$ & $\begin{array}{l}\text { 19b. TELEPHONE NUMBER (include area code) } \\
443-757-5802\end{array}$ \\
\hline
\end{tabular}



